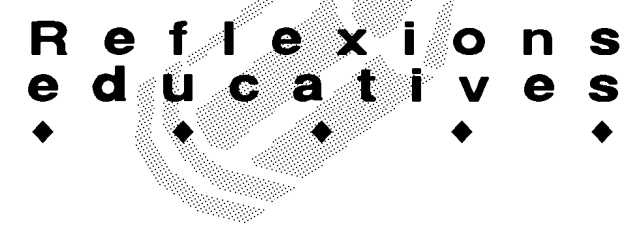

\title{
ANÀLISI DELS RESULTATS DE L'AVALUACIÓ DE LES COMPETĖNCIES BÀSIQUES
}

\author{
Rosa M. Montseny Baulenas. Mestra del CEIP "Sant Jordi”. L'Ametlla de Mar
}

\section{Introducció}

Quan es realitza l'anàlisi qualitativa dels resultats d'unes proves de competències bàsiques, com és el cas, s'ha de tenir molt clar que no ens podem quedar en uns resultats, sinó que cal identificar tot allò que necessita l'alumne/a per assolir unes competències i reflexionar i plantejar les vies necessàries per millorar-ne l'assoliment.

L'anàlisi de resultats, per una banda, ens ajuda a comprovar que anem bé i, per altra banda, a identificar necessitats $\mathrm{i}$ analitzar determinades actuacions per plantejar, rectificar, ajustar estratègies d'ensenyament $i$ millorar l'assoliment de les competències bàsiques en l'alumnat. Això comporta una presa de decisions consensuades sobre el currículum i la metodologia a usar, no tan sols en el cicle mitjà, sinó també en els cicles inicial i superior. Les decisions preses queden reflectides en el pla d'avaluació interna del centre (extret del document proves d'avaluació de les competències bàsiques d'educació primària. Cicle mitjà).

L'objectiu del treball és reflexionar i discutir en el si del claustre sobre els resultats de les proves, i facilitar la presa de decisions sobre aspectes de gestió del currículum i dels resultats d'aprenentatge.

Des del punt de vista del procés, amb l'objectiu de reflexionar i prendre decisions, hem de distingir dues fases metodològiques: Representació de resultats i anàlisi de resultats.

\section{Anàlisi dels resultats}

Un cop realitzades i corregides les proves, expressem els resultats, obtinguts per cadascuna de les competències dels diferents àmbits, en forma de percentatge, tot comparant-los amb els resultats obtinguts en el curs passat, i en fem una primera lectura.

Competències de l'àmbit matemàtic. Les competències d'aquest àmbit es troben llistades a la taula 1.

Comparant els resultats de la taula 1, es poden fer els següents comentaris:

- Els alumnes han millorat en el càlcul mental amb temps controlat i no controlat. Tot i això, s'ha de seguir treballant a les aules.

- El nivell d'assoliment en la composició i descomposició de formes geomètriques ha baixat, encara que el nivell és acceptable.

- Els resultats obtinguts en l'ús d'instruments i tècniques amb l'ordinador no són gaire satisfactoris. Els resultats obtinguts són punt de reflexió i anàlisi sobre l'ús que fem de l'ordinador com a eina i com a recurs dins del procés d'ensenyament i aprenentatge.

- Es manté el nivell d'assoliment pel que fa al càlcul aproximat, l'ús d'instruments i tècniques per dibuixar, mesurar i calcular a mà, l'ús i interpretació de llenguatge matemàtic en un gràfic, i de la funció dels nombres en contextos reals.

Competències de l'àmbit lingüístic. A la taula 2 es llisten els percentatges que assoleixen les competències de l'àmbit lingüístic en allò que fa referència a la llengua catalana. Les dades corresponents a la llengua caste-

\begin{tabular}{|c|c|c|c|}
\hline & Competència bàsica & $\begin{array}{r}\% \text { Curs } \\
\underline{02-03}\end{array}$ & $\begin{array}{r}\% \text { Curs } \\
01-02 \\
\end{array}$ \\
\hline M1A & Càlcul exacte amb temps controlat. & 67,44 & 35,50 \\
\hline M1B & Càlcul exacte amb temps no controlat. & 69,76 & 51,11 \\
\hline M1C & Càlcul aproximat. & 72,09 & 71,11 \\
\hline M2 & $\begin{array}{l}\text { Compondre i descompondre formes } \\
\text { geomètriques. }\end{array}$ & 65,11 & 75,55 \\
\hline M3 & Emprar amb criteri les unitats de mesura. & a. 86,04 & 84,44 \\
\hline M4A & $\begin{array}{l}\text { Usar amb propietat instruments i tècni- } \\
\text { ques per dibuixar, mesurar i calcular, } \\
\text { quan sigui necessari. A mà. }\end{array}$ & 95,34 & 75,55 \\
\hline M4B & $\begin{array}{l}\text { Usar amb propietat instruments i tèc- } \\
\text { niques per dibuixar, mesurar i calcular, } \\
\text { quan sigui necessari. Amb ordinador. }\end{array}$ & 55,81 & \\
\hline M5 & $\begin{array}{l}\text { Planificar i seguir alguna estratègia per } \\
\text { resoldre un problema i modificar-la, si } \\
\text { no és prou eficaç. }\end{array}$ & 67,44 & 48,88 \\
\hline M6A & $\begin{array}{l}\text { Usar i interpretar dibuixos per descriure } \\
\text { fenòmens quotidians. Signes i Xifres. }\end{array}$ & 83,72 & 95,55 \\
\hline M6B & $\begin{array}{l}\text { Usar i interpretar gràfics per descriure } \\
\text { fenòmens quotidians. Gràfic. }\end{array}$ & 88,37 & 68,88 \\
\hline M7 & $\begin{array}{l}\text { Interpretar i usar la funció que fan els } \\
\text { nombres en un context determinat. }\end{array}$ & 74,41 & 51,11 \\
\hline
\end{tabular}

Taula 1. Competències de l'àmbit matemàtic 


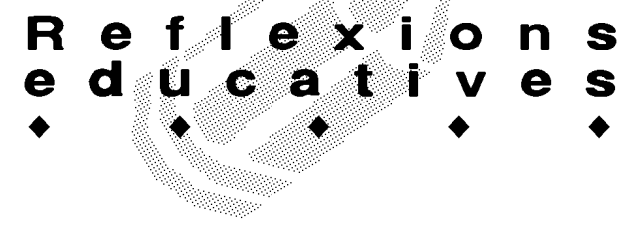

Ilana i a l'anglesa s'han reflectit a les taules 3 i 4, respectivament.

Comparant els resultats de la llengua catalana (taula 2), es poden fer els següents comentaris:

- El percentatge d'alumnat que és capaç de comprendre i interpretar el que llegeix ha millorat.

- L'alumnat sap expressar-se oralment de manera clara i ordenada, usant el lèxic i estructures morfosintàctiques adequades.

- Els resultats en la competència lectora han millorat i són satisfactoris.

- Els resultats en expressió escrita han millorat

\section{Competència bàsica}

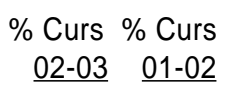

L11 Comprendre la informació explicitada en un text escrit per poder extreure allò que interessa en funció dels objectius de la lectura (comprensió textual literal).

$72,09 \quad 64,44$

L12 Comprendre un text escrit interpretant el missatge a partir de la informació que conté i els coneixements propis (comprensió textual inferencial/interpretativa).

$83,72 \quad 77,77$

L13 Expressar-se oralment adequant-se a la situació comunicativa i al receptor amb ordre i claredat (component discursiu).

$95,34 \quad 73,33$

L14A Expressar-se oralment aplicant correctament els coneixements lingüístics pel que fa a lèxic i estructures morfosintàctiques (components lingüístics). Competència lingüística.

$81,3986,66$

L14B Expressar-se oralment aplicant correctament els coneixements lingüístics pel que fa a lèxic i estructures morfosintàctiques (components lingüístics). Lèxic.

L16 Produir un text escrit adequat a la necessitat comunicativa i al receptor, amb ordre i claredat (organització del text).

L17 Produir un text escrit aplicant correctament els coneixements lingüístics pel que fa a lèxic, ortografia i estructures. morfosintàctiques (correcció lingüística). Ortografia dictat.

$76,74 \quad 71,11$

L18 A Produir un text escrit amb grafia clara i llegible, tot seguint les pautes de presentació de treballs escrits (presentació i grafia). Manuscrit.

$79,06 \quad 80,00$

L18 B Produir un text escrit amb grafia clara i llegible, tot seguint les pautes de presentació de treballs escrits (presentació i grafia). Ordinador.

58,13

Taula 2. Competències de l'àmbit lingüístic (Ilengua catalana) respecte al curs passat.

- En l'organització textual (L16 i L17) els alumnes tenen més fluïdesa per produir un text en llengua catalana, mentre que els resultats indiquen que, a nivell lèxic, ortogràfic i morfosintàctic mostren més facilitat per produir un text en llengua castellana.

- Si comparem els resultats dels cursos 2001-02 i 2002-03, observem que la millora és considerable. De tota manera, cal seguir insistint en la comprensió lectora i en l'expressió escrita.

\begin{tabular}{|c|c|c|c|}
\hline & $\underline{\text { Competència bàsica }}$ & $\begin{array}{r}\% \text { Curs } \\
\underline{02-03}\end{array}$ & $\begin{array}{r}\% \text { Curs } \\
\underline{01-02}\end{array}$ \\
\hline L12 & $\begin{array}{l}\text { Comprendre un text escrit interpretant } \\
\text { el missatge a partir de la informació que } \\
\text { conté i els coneixements propis (compren } \\
\text { sió textual inferencial / interpretativa). }\end{array}$ & 83,72 & 77,77 \\
\hline L15A & $\begin{array}{l}\text { Interpretar la correspondència grafia-so i } \\
\text { els signes de puntuaciód'una lectura amb } \\
\text { correcció fonètica i amb l'entonació ade- } \\
\text { quada. }\end{array}$ & $\begin{array}{l}\mathrm{i} \\
\mathrm{ib} \\
- \\
95,34\end{array}$ & 60,00 \\
\hline L15B & Mecànica de la lectura. & 93,00 & 91,11 \\
\hline L15C & Velocitat lectora. & 97,64 & 60,00 \\
\hline L16 & $\begin{array}{l}\text { Produir un text escrit adequat a la neces- } \\
\text { sitat comunicativa i al receptor, amb ordre } \\
\text { i claredat (organització del text). }\end{array}$ & Ire & 57,77 \\
\hline L17 & $\begin{array}{l}\text { Produir un text escrit aplicant correcta- } \\
\text { ment els coneixements lingüístics pel que } \\
\text { fa a lèxic, ortografia i estructures morfo- } \\
\text { sintàctiques (correcció lingüística). Orto- } \\
\text { grafia dictat. }\end{array}$ & 92,30 & 71,11 \\
\hline
\end{tabular}

Taula 3. Competències de l'àmbit lingüístic (Ilengua castellana)

\section{Relació entre les competències bàsiques i els nivells d'assoliment}

A continuació es relacionen les diferents competències bàsiques de l'àmbit matemàtic i lingüístic, amb els diferents nivells d'assoliment, de la forma següent: nivell baix (menys del $50 \%$ ); nivell mitjà (del 50 al $70 \%$ ); nivell alt (del 70 al $90 \%$ ) i nivell molt alt (del 90 al 100\%).

Val a dir que el centre determina com a criteri de domini o bondat d'assoliment d'una determinada competència quan s'arriba a un percentatge comprès entre el 65 i el $70 \%$.

Pel que fa als nivells d'assoliment de l'àmbit matemàtic, només la competència M4A (Usar amb propietat instruments $i$ tècniques per dibuixar, mesurar i calcular quan sigui necessari. A mà) té un nivell "molt alt” (95,34\%). 


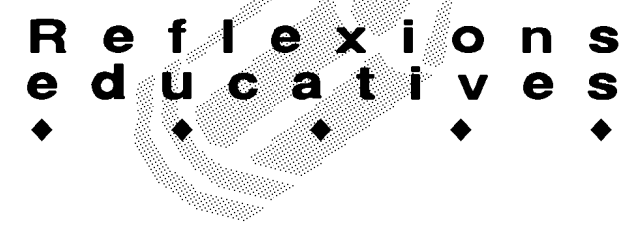

Les de nivell "alt" són: M6B (usar i interpretar gràfics per descriure fenòmens quotidians), 88,37\%; M3 (emprar amb criteri les unitats de mesura), 86,04\%; M6A (usar i interpretar dibuixos per descriure fenòmens quotidians. Signes i xifres), 83,72\%; M7 (interpretar i usar la funció que fan els nombres en un context determinat), $74,41 \%$, i M1C (càlcul aproximat),72,09\%.

La resta s'ubica al "nivell mitjà": M1B (càlcul exacte amb temps no controlat), 69,76\%; M1A (càlcul exacte amb temps controlat), 67,44\%; M5 (planificar i seguir alguna estratègia per resoldre un problema i modificar-la, si no és prou eficaç), 67,44\%; M2 (compondre i descompondre formes geomètriques), 65,11\% i M4B (usar amb propietat instruments $\mathrm{i}$ tècniques per dibuixar, mesurar $\mathrm{i}$ calcular quan sigui necessari. Amb ordinador), 55,81\%.

\begin{tabular}{|ll|}
\hline L9 & $\begin{array}{l}\text { Competència bàsica } \\
\text { Comprendre la informació explicitada en } \\
\text { un text oral i extreure'n allò que interessa }\end{array}$ \\
& en funció dels objectius de la situació co- \\
municativa (comprensió oral literal). & 01-02 \\
L14 & Expressar-se oralment aplicant correc- \\
tament els coneixements lingüístics pel \\
que fa al lèxic i estructures morfosintàc- \\
tiques (components lingüístics). Compe- \\
tència lingüística.
\end{tabular}

Taula 4. Competències de l'àmbit lingüístic (llengua anglesa)

Si observem els resultats obtinguts en l'àmbit matemàtic i establim diferents nivells d'assoliment, podem veure amb més claredat que, en general, cal reforçar prioritàriament les competències següents: M4B (usar amb propietat instruments i tècniques per dibuixar, mesurar i calcular, quan sigui necessari. Amb ordinador) i M2 (compondre i descompondre formes geomètriques), i seguir treballant en la mateixa línia pel que fa a les competències: M1A i M2B (càlcul mental) i M5 (resolució de problemes).

En l'àmbit lingüístic, els resultats són millors. Hi ha quatre competències que se situen al nivell "molt alt": L14B (expressar-se oralment aplicant correctament els coneixements lingüístics pel que fa a lèxic i estructures morfosintàctiques), 100\%; L13 (expressar-se oralment adequant-se a la situació comunicativa i al receptor amb ordre i claredat ), 95,34\%; L15A (interpretar la correspondència so-grafia $i$ els signes de puntuació d'una lectura amb correcció fonètica i amb l'entonació adequada), 95,34\%, i L15B (mecànica de la lectura), 93,00\%.

La resta són al "nivell alt": L9 (comprendre la informació explicitada en un text oral i extreure'n allò que interessa en funció dels objectius de la situació comunicativa), 88,37\%; L12 (comprendre un text escrit interpretant el missatge a partir de la informació que conté i els coneixements propis), 83,79\%; L14A (expressar-se oralment aplicant correctament els coneixements lingüístics pel que fa a lèxic i estructures morfosintàctiques), 81,39\%; L18 (produir un text escrit amb grafia clara i llegible), 79,06\%; L11 (comprendre la informació explicitada en un text escrit per poder extreure allò que interessa en funció dels objectius de la lectura), 72,09\%; L16 (produir un text escrit adequat a la necessitat comunicativa i al receptor, amb ordre i claredat), $83,72 \%$ i L17 (produir un text escrit aplicant correctament els coneixements lingüístics pel que fa a lèxic, ortografia i estructures morfosintàctiques),76,74\%.

En aquest àmbit els resultats obtinguts són força satisfactoris, encara que caldrà seguir insistint en la millora de la competència L11 (comprensió d'un text escrit, tant en català com en castellà). De tota manera, els resultats en aquesta competència han millorat respecte a cursos anteriors.

Finalment, comparem els resultats obtinguts pel centre amb els de Catalunya, calculant la diferència percentual entre els valors obtinguts al centre amb els de la mitjana aritmètica de Catalunya. Els valors positius indiquen que el centre es troba per damunt dels valors obtinguts a Catalunya. En cas negatiu, signifiquen el contrari.

$\begin{array}{cc}\text { Competència bàsica } & \text { Diferència en } \% \\ \text { M1A } & +4,44 \\ \text { M1B } & +11,76 \\ \text { M1C } & +9,09 \\ \text { M2 } & +2,09 \\ \text { M3 } & +0,04 \\ \text { M4A } & +0,34 \\ \text { M4B } & -33,19 \\ \text { M5 } & -2,50 \\ \text { M6A } & +5,72 \\ \text { M6B } & +12,37 \\ \text { M7 } & +3,41\end{array}$

En comparar els resultats obtinguts pel centre amb els de Catalunya, s'observa que les diferències percentuals majoritàriament no són significatives. Ara bé, cal destacar que en l'àmbit matemàtic, en l'ús de l'ordinador (M4B), la mostra de Catalunya té una diferència percentual al seu favor de 33,19\% i en la resolució de problemes (M5) de 2,5\%. Aquest fet implica una reflexió, tal com ja havíem constatat en resultats, sobre l'ús de l'ordinador i la resolució de problemes.

Pel que fa a l'àmbit de la llengua, les diferències percentuals entre els valors obtinguts al centre amb els d'una mostra de Catalunya s'analitzen en el cas de les 


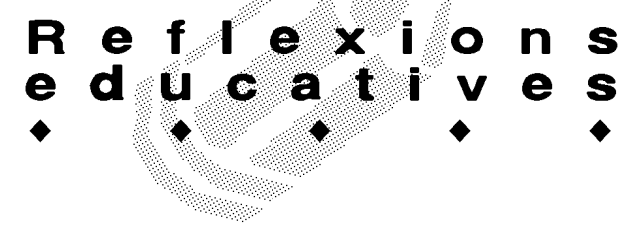

tres llengües: anglesa, catalana i castellana.

Els resultats de la llengua anglesa són:

$\begin{array}{cc}\text { Competència bàsica } & \text { Diferència en \% } \\ \text { L9 } & +2,3 \\ \text { L14 } & -11,60\end{array}$

Pel que fa a la llengua catalana, són:

Competència bàsica Diferència en \%

$\begin{array}{lr}\text { L11 } & +0,09 \\ \text { L12 } & +8,70 \\ \text { L13 } & +6,34 \\ \text { L14A } & -11,60 \\ \text { L14B } & +5,00 \\ \text { L16 } & +12,70 \\ \text { L17 } & +5,70 \\ \text { L18A } & -10,90 \\ \text { L18B } & -11,80\end{array}$

Finalment, pel que fa a la llengua castellana, les diferències són:

$\begin{array}{cc}\text { Competència bàsica } & \text { Diferència en } \% \\ \text { L12 } & +8,7 \\ \text { L15A } & +8,3 \\ \text { L15B } & +14,00 \\ \text { L15C } & +12,00 \\ \text { L16 } & +12,00 \\ \text { L17 } & +5,00\end{array}$

Quant a l'àmbit lingüístic en Ilengua catalana, cal destacar una diferència percentual a favor de la mostra representativa de Catalunya en "l'expressió oral" (L14A) i en la "producció d'un text escrit amb grafia clara... en manuscrit i ordinador" (L18A i L18B).

És curiós observar com en llengua castellana l'assoliment de les competències de l'àmbit lingüístic és més favorable que en llengua catalana. En anglès cal vigilar l'expressió oral.

\section{Proposta de millora d'algunes competències}

L'anàlisi i la interpretació dels resultats s'ha fet considerant les característiques de cada grup d'alumnes i s'ha determinat, com ja s'ha dit abans, un criteri de bondat o de domini a partir del qual considerem satisfactoris com a centre els resultats. En el nostre cas s'ha fixat en el $65-70 \%$. També s'han constatat les dificultats i s'han analitzat les possibles causes per les quals un determinat nombre d'alumnes no encerten la resolució d'una activitat concreta.

Un cop analitzats i interpretats els resultats obtinguts, i després de reflexionar i discutir sobre els resultats en el si del claustre de professors, abans de fer propostes concretes de millora s'ha tingut en compte que cal:

- Procurar que les propostes sempre estiguin vinculades a les causes i prioritzar-les segons criteris (les considerades més importants pels equips, les que es poden treballar en les diferents àrees, etc).

- Entendre que alguns canvis es poden assumir amb més facilitat. Ex: diversificar i seleccionar més els materials.

- Considerar que en alguns casos convindria fer un treball més aprofundit, i per tant s'hauran de prioritzar algunes competències.

- Revisar criteris per seleccionar les activitats d'un llibre. Ex: prioritzar activitats més cognitives més que no pas repetitives, activitats que formulin les preguntes de forma clara i precisa...

- Identificar les rutines d'aula, que poden ser un procediment important per consolidar algunes competències bàsiques (la representació gràfica i la interpretació de la temperatura en un temps, la realització d'activitats de càlcul mental de manera sistemàtica, el treball metòdic de lectura seguint unes pautes, la realització de dictats...).

Tenint present tot el que s'ha dit fins ara, es formulen les següents propostes de millora:

Competència: M4B. Usar amb propietat instruments i tècniques per dibuixar, mesurar i calcular, quan sigui necessari. Ordinador.

Resultat: Ho superen un 55,81\%

Constatació: Els alumnes mostren problemes en el moment d'utilitzar el processador de textos i el programa de dibuix.

Anàlisi causal i valoració: Fins ara el professorat ha utilitzat l'ordinador com a recurs, per reforçar els continguts treballats a l'aula, diversificar la metodologia..., I s'ha deixat una mica de banda el fet d'utilitzar l'ordinador com a eina i com a finalitat. Aquest fet ha provocat que l'alumnat tingui unes mancances en el moment d'utilitzar les eines del Word o del Paint.

Propostes de millora: Durant el curs 2002-2003 es va iniciar la revisió metodològica de l'ús de l'ordinador i la introducció en les programacions del processador de textos, de programes de dibuix, de l'ús d'Internet...

Competència: M2. Compondre i descompondre formes geomètriques.

Resultat: Ho superen un $65,11 \%$.

Constatació: Mostren dificultats per reproduir les tres dimensions.

Anàlisi causal i valoració: Dins la seqüència de continguts de geometria que s'imparteixen als cicles, no es té en compte el desenvolupament cognitiu de l'infant pel que fa a la geometria. És a dir, no tenim en compte que l'infant percep les figures d'una manera global i no partim d'un treball experimental del món tridimensional de les formes, dels objectes més comuns, que formen part de l'entorn i comencem pel punt, línia, recta, tipus de rectes...

Propostes de millora: Aquest curs el professorat del 


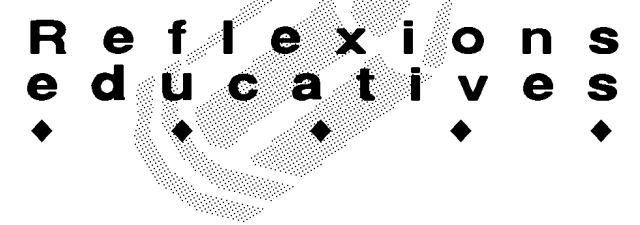

centre realitza un curs de geometria i mesura, a través del qual es pretén revisar la seqüència de continguts i la metodologia utilitzada pel que fa a la geometria a Primària.

Competència: M5. Planificar i seguir alguna estratègia per resoldre un problema i modificar-la, si no és prou eficaç.

Resultat: Ho superen un 67,11\%

Constatació: Mostren dificultats per usar estratègies en el moment d'establir relacions i resoldre el problema. La metodologia utilitzada en el procés d'ensenyança/ aprenentatge potser no és l'adequada. Cal revisar la metodologia marcant-nos com a objectiu que l'alumne/a ha d'aprendre a pensar, li hem d'engegar un procés reflexiu, ha de ser capaç d'establir relacions, realitzar una anàlisi, buscar, predir, rectificar, usar estratègies diverses en contextos, situacions diferents amb un enfocament funcional

Propostes de millora: Els resultats obtinguts no són dolents, però potser no són els que esperàvem. Donat que aquest any s'imparteix al centre un curs de matemàtiques, hem parlat amb el formador perquè ens orienti en la resolució de problemes des d'una perspectiva constructivista.

Competència: L 14A. Expressar-se oralment, aplicant correctament els coneixements lingüístics pel que fa a lèxic i estructures morfosintàctiques (component lingüístic). Competència lingüística.

Resultat: Ho superen un $81,39 \%$. Però hi ha una diferència percentual d'un $11,6 \%$ a favor de la mostra de Catalunya.
Constatació: Els resultats obtinguts no són dolents, però hi ha una diferència percentual que provoca una anàlisi dels resultats. Els alumnes mostren, en certa manera, una falta de vocabulari i els costa expressar les seves idees de manera coherent, usant connectors adequats, evitant repeticions. Cal crear situacions, preparar activitats com pot ser la presentació en veu alta d'un argument, defensar un parer davant una situació... de manera que ampliem el ventall expressiu de l'alumnat alhora que aquest utilitza estratègies de conversa d'exposició oral.

Propostes de millora: Revisar les activitats que proposem a l'alumnat per treballar l'expressió oral, així com les estratègies que es posen en joc en el desenvolupament d'una activitat.

\section{Valoració de l'aplicació de les proves}

Les proves de competències bàsiques ens permeten, al conjunt del professorat, justificar la proposta de canvis metodològics i definir una avaluació interna i un pla estratègic que ens ajudaran a donar resposta a totes aquelles necessitats que presenten els alumnes. Perquè no hem d'oblidar que l'objectiu és millorar la qualitat de l'ensenyament, és facilitar la construcció de coneixements en l'alumnat de manera que aquests puguin desenvolupar-se amb èxit dins una societat tan canviant com la nostra.

Cal vetllar per la continuïtat i l'aplicació d'aquests tipus de proves i consolidar les propostes de canvi que hagin estat útils.

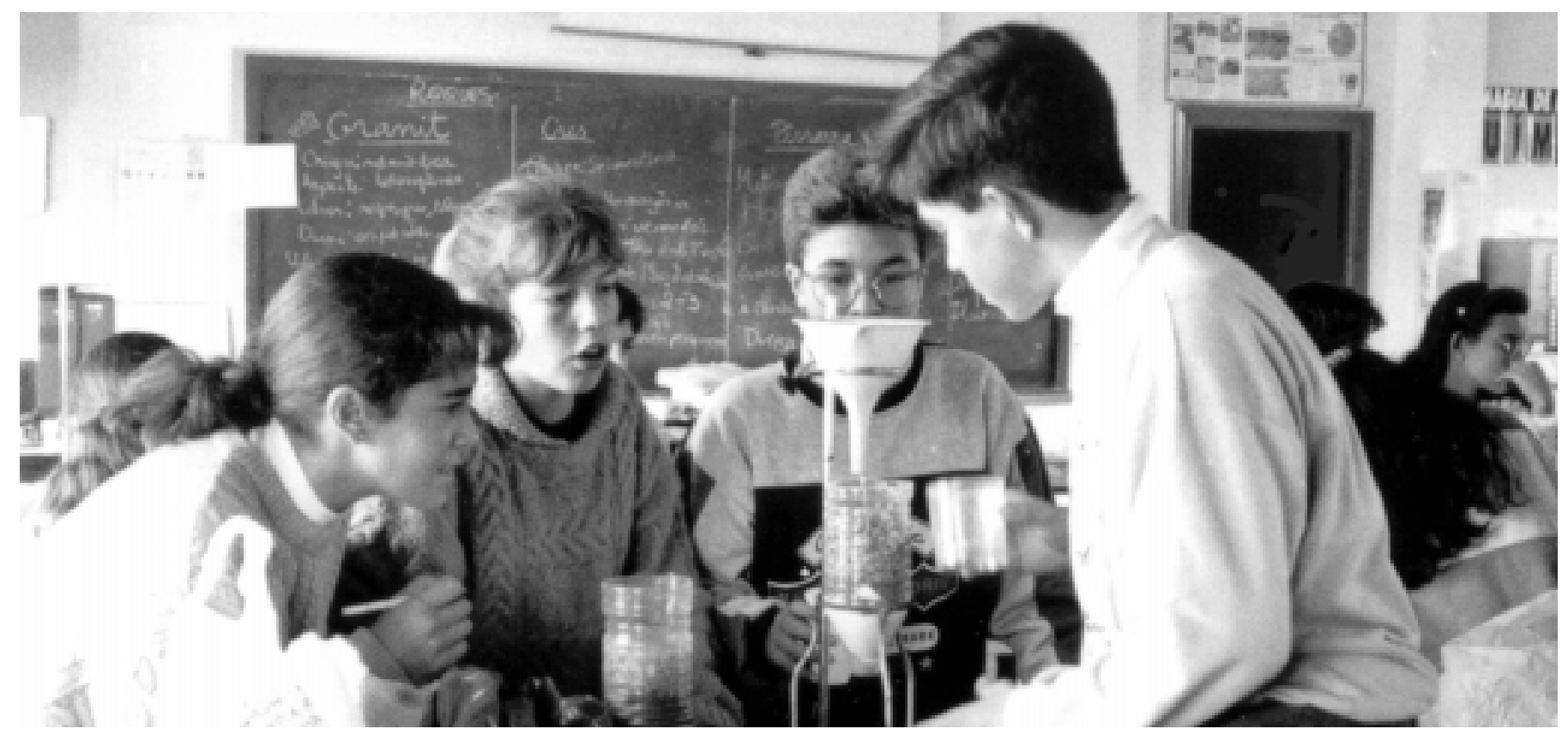

